\title{
A Conceptual Overview of Risk Management in Education Sector Projects
}

\author{
Ms. Padmajah Narasimhan \\ Independent Researcher \\ Bengaluru, Karnataka, India
}

\begin{abstract}
Risk management is one of the important areas for implementation of any project and more precisely in the education sector. The conceptual research on risk management in projects within education sector is one of the key focus areas, which helps in identifying the circumstances leading to actualization. The outcomes that can arise while establishing a risk management framework in education projects can reduce the chances of effective reduction of risks. This requires a leading approach like categorization of risks to implement the same. Furthermore, in the perspective of modern educational risk management, rationality leading to risks formulates the effective risk handling process in a methodical and organizational condition. The outcome of risk management can favour the creation of effective and efficient risk management models along with strategies in the sphere of education. The present research study focuses on helping the educational employees into designing, planning, implementing, monitoring and evaluating the educational projects at various levels of the organization in order to manage the risks associated with it.
\end{abstract}

Keywords: Risk Management, Education, Projects, Framework, Organization.

\section{Introduction}

Education sector is regarded as a critical factor influencing the economic growth and development of human resources. The basic aim of the education sector is to improve the quality of education, wherein its primary objective is to empower the individual with skills and knowledge required to participate in any reforms of the state apparatus. The education sector is big and regarded as the important sector of state apparatus. The state devises strategies and reforms in education sector in the form of projects. The projects in education are prone to risks during the implementation process and risk management strategy is absolutely essential to achieve the project goals. The project implementation in education sector has inherent risks, which can be similar or different as that of the projects in other public sectors. The risk management projects will involve both education and governance specialists in all the countries. There is a structured approach involved 
in designing the projects and it helps the governance specialists to explore the areas which are vulnerable to risks in a governance perspective. The education projects must aim at revisiting the key prospects of education sector and map the vulnerable pointers with the risks as explored by the governance specialists (Berg, 2010). Some of the common risks in education projects in these countries are weak institutions, lack of proper governance and exceeding corruption affecting the stability of education institutions at all levels. These risks also affect the sustainability of the education projects as they directly affect the financial management of the institution. The development of education projects is based sector analysis of risks involved in terms of economic and governance perspective.

Education sector is quite different than other public sectors as the students prefer to use their knowledge and skills acquired through education projects in to other public sectors due to various reasons like employment prospects and revenue generation. Hence, education sector is regarded as a fundamental block in reducing the poverty, developing skilled human resources for other public sector and also promote growth of economy. The field of study in education sector can be focused based on interest and it is evident that only individuals who work in higher education profile will be predominantly researchers or graduates in natural sciences. Moreover, it helps in meeting the demand and market needs of the labour sector by increasing productivity of skills leading to more sustainability in other sectors. The education sector sows the seed of lifelong learning for development of individual and social acceptance through its basic education. The numeracy, literacy and competency skills will prepare students to take up higher level career options like managers, technical engineers and administrative leaders. Thus, education sector plays a pivotal role in scaling up the economy and also improvement of technology in other public sectors.

\section{Literature Review}

The strategic framework of education projects are based on risks associated with inclusion, infrastructure, lack of quality, lack of availability of education assistance. The framework supports five critical areas for risk management for education project focusing on increasing and continuing the loans and assistance for higher studies, strengthening the aspects of skills, quality and inclusiveness at all levels of education, to include new and innovation models for improving service capabilities, to promote more scope cross border collaboration and regional level cooperation (Larman, 2004). In furtherance, the Legal framework in education sector will include clear allocation and accountability of functions related to education services, right to education, accreditation and registration process of educational institutions, certification process for teachers and progressive career graph, education loan and admission processes. The risk associated in education sector in a legal perspective are lack of gender equality where girl child is not allowed to go to 
school, corruption and noncompliance to the legal framework affecting the quality of the education as a whole (Boehm \& Turner, 2003).

\section{Key Features of Education Sector}

The key features of education sector include frameworks like:

$>$ Institutional rights including the legal framework, policies and regulatory schemes from the government.

$>$ Organizational aspects like planning strategies, financial management like budgeting, incentivising, management strategies, procurement decisions and practices and effective human resources to manage the dynamic projects of education sector.

$>$ Sectorial operations in education sector will include processing student admissions, teacher recruitments, development of curriculum and learning tools and issue of certificates, degrees or diplomas, administration of school and supervision and development of capacity at all district levels.

\section{Specifics of Projects in Education sector}

The projects in education sector aims at the development of specific parameters like improving the accessibility of education and ICT in rural areas, educational equality and strengthening the education system in the streams of technical, vocational and higher education. The specific factors to be focused while planning an educational project are the areas of improvement in terms of quality of learning and teaching process, curriculum and desired outcomes (Popescu \& Dascalu, 2011). Also, some of the education projects will be based on core functions like procurement focusing on distribution of text books and accessibility of learning tools in rural areas by effecting planning at all levels of education. In Japan and Russia, the private sectors also get involved in the education projects in order to support the government in specific projects like improving literacy rates; promote education of girl child, improving the capacities at physical and human level for better results. The countries like United Kingdom and United States of America are keen in introducing new innovative education projects to have special focus on pedagogic movement and quality monitoring in order to improve the human resources which are integral part of the education sector.

\section{Need \& Significance}

We need to research on the risk management in Education sector as it has a greater influence in the key decision making process involving educational reforms and development. Moreover, such decision making is critical to eliminate the risks associated with the educational projects and it is significant among countries as it has direct impact on the economic, social and environmental wellbeing of the 
country (Thywissen, 2004). The decision making process is very critical in a risk environment in projects in the education sector as it can hamper the core functioning of the educational projects and the desired outcomes leading to failure of educational reforms leading to crisis situations like lack of school safety, child safety, decreased quality of education etc. The risks which can occur due to lack of effective decision making process are miscalculation on allocation of government expenditure in the educational reforms, not availing the scope of taking decisions under discrete situations, disturbance and interference caused by politicians and stakeholders, easy approvals for ineffective educational institutions (Boehm \& Turner, 2003). Moreover, the risk management can be focused on the clusters like: competency management, standardized content, updated learning process, personal safety \& accommodation to teaching and non-teaching staffs, uniformity in the education infrastructure \& equipment, clear protocols \&standard operating procedures (SOPs) for management of educational institutions, optimization strategies to normalize the finance and cost of education (Ruzic-Dimitrijevic \& Nikolic, 2008). Hence, there is a need to conceptually under the risk management process in education sector.

\section{Objectives}

$>$ To conceptually review the risk management aspects in education sector and discuss its proven framework

$>$ To understand the mapping of risk management parameters in education sector projects and study its impact

\section{Risks in Education Sector Projects}

The governance risks in education projects are the challenges in the allocation of government expenditure for education, opportunities for taking decisions, capacity of institutionalism is less, various disturbances like interference from politicians and existence of vulnerability in terms policy formulation, procurement of various tools for education, human resource challenges and operational risks and deviation of regulatory measures by policy makers, teachers, students and parents (Nikolic \& Ruzic-Dimitrijevic, 2013). For instance, some of the risks associated with education projects are extra charge for tutoring the students, lack of disaster preparedness in schools and inadequate school infrastructure (Berg, 2010).

\section{Risk Management in Education Projects}

The risk management process is based on the corrective actions or strategies which help in combating against the risks identified within the educational system (Berg, 2010). Furthermore, the education system is fairly competitive and each country has to devise their strategy towards risk management in order to scale up their ranking in the education system according to OECD survey. If there is no proper risk 
management reform in educational projects, then there will lag in social and economic development of the country. The governance of risks in the education sector can be better controlled by framing educational policies based on problem areas about that country in a social and economic perspective (Nikolic \& RuzicDimitrijevic, 2010).

The risks in education sector projects can be managed by using the innovative thoughts, knowledge and value based education leading to a more resilient and safe education sector. The risks associated with the framework of projects in education sectors for each scenario along with corrective management measures are indicated in the below table.

\section{Table 1: Categories of Risks Associated in Education Projects}

\begin{tabular}{|c|c|c|}
\hline Institutional Risks & Organizational Risks & Sectorial Risks \\
\hline $\begin{array}{l}\text { Institutional focus } \\
\text { framework involves the } \\
\text { legal clauses in } \\
\text { education, the policies } \\
\text { and regulatory quality } \\
\text { monitoring systems. The } \\
\text { purpose is to improve } \\
\text { the transparency in the } \\
\text { education sector and } \\
\text { achieve the desired } \\
\text { quality standards. } \\
\text { Institutional risks in } \\
\text { educational department } \\
\text { may arise out due to the } \\
\text { following scenarios } \\
\text { (Prichinin, 2013) }\end{array}$ & $\begin{array}{l}\text { Organizational Risks will } \\
\text { evolve in the process of } \\
\text { planning like allocation of } \\
\text { funds for schools, data } \\
\text { manipulation and non- } \\
\text { compliance in school } \\
\text { locations Financial } \\
\text { management like risks } \\
\text { associated with low } \\
\text { budget, misuse of funds, } \\
\text { inadequate monitoring of } \\
\text { education documents and } \\
\text { failure in auditing the } \\
\text { same, poor information } \\
\text { system damaging the } \\
\text { allocation of required } \\
\text { resources }\end{array}$ & $\begin{array}{l}\text { Sectorial Risks are } \\
\text { associated with the } \\
\text { process of admission of } \\
\text { students, scholarships for } \\
\text { deserving students, } \\
\text { quality of curriculum and } \\
\text { learning tools, } \\
\text { certification and training } \\
\text { programs for teachers, } \\
\text { student assessment and } \\
\text { overall administration of } \\
\text { the school. }\end{array}$ \\
\hline $\begin{array}{l}\text { Example and Risk } \\
\text { Impact } \\
\text { The policy framework } \\
\text { for education sector is } \\
\text { not aligned with risks } \\
\text { associated and it creates } \\
\text { more impact on the } \\
\text { people. There is clear } \\
\text { bias in the allocation of } \\
\text { funds to schools and the }\end{array}$ & $\begin{array}{l}\text { Example and Risk } \\
\text { Impact } \\
\text { The financial losses and } \\
\text { implications arising due to } \\
\text { lack of capacity of } \\
\text { financial management, lack } \\
\text { of effective auditing } \\
\text { systems. } \\
\text { There is no clarity on data }\end{array}$ & $\begin{array}{l}\text { Example and Risk } \\
\text { impact } \\
\text { The manipulative risks } \\
\text { arising out due to lack of } \\
\text { transparency in the } \\
\text { certification process and } \\
\text { processing the results of } \\
\text { examination. This is } \\
\text { higher degree of risk in }\end{array}$ \\
\hline
\end{tabular}




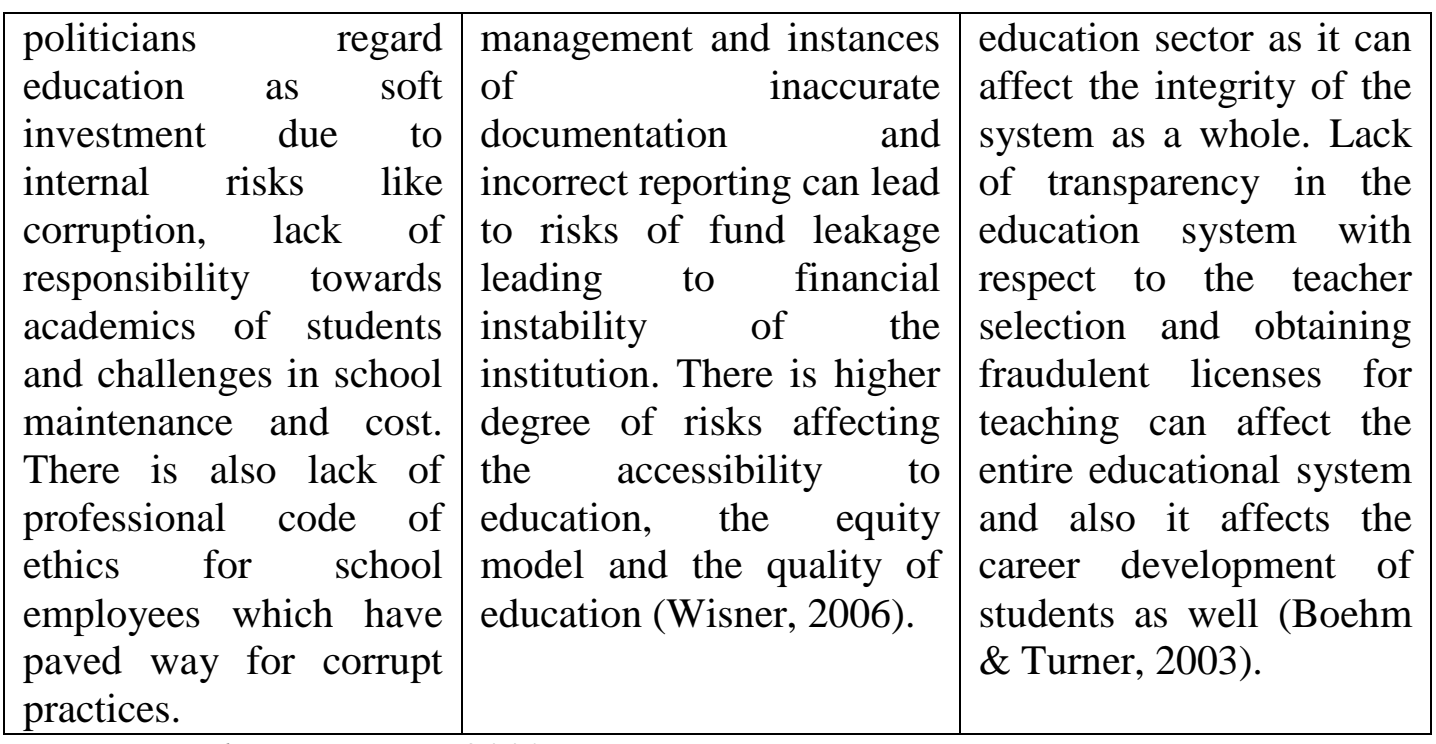

Source: Boehm \& Turner, 2003

\section{Discussion}

The lack of accountability is one of the reasons of risk in decision making process and it can lead to very poor service capabilities, leakage of resources and increases the chances of misalignment of goals and actions leading to non-compliance of education reforms (Huber, 2009). The key stakeholders in educational projects of the countries are policy planners, makers and researchers, the legal board members who do the certification and accreditation process, educational faculties and mentors, stationery suppliers, external investors and partners, workers unions for teachers and school managements, entities like judiciary for any legal battles and audit professionals (Popescu \& Dascalu, 2011). The potential risks in stakeholder management can be identified by creating an informal or formal relationship with all the stakeholders. The faculties may be recruited in a partial manner without validating and assessment of qualification and faculties without any recommendation can be assigned to remote and challenging locations. The lack of discipline in conducting exams and sale of assessment questions are potential risks which are controlled by stakeholders (Boehm \& Turner, 2003). Also, stake holder analysis is very critical in terms of successful functioning of educational projects. The risk management process of stake holders will involve the following:

1. Inculcating accountability for the stakeholders and mapping it with their demand (Huber, 2010).

2. To propose a clear and transparent framework to regulate resource allocation process.

3. To conduct economic and political analysis in a stake holder's perspective in order to identify the problem areas and their impact on the government policies 
and explore alternate strategies to combat against the risks in governing the educational projects (Huber, 2010).

4. Risks associated with stakeholders can hamper the core functioning of the educational projects and it can create detrimental effect on the governance and economy of the country if there is no proper risk management strategy.

In the recent years, there are many effective risk management strategies like brainstorming, risk assessment, root cause analysis, impact matrix, etc. are in practice. However, the risk management effectiveness can be achieved by adopting individual and / or combination of all the aforementioned strategies for successful implementation of education project within the time frame.

\section{Suggestions}

Effective risk management in education sector if the sector standardizes the learning framework and create more opportunities based on skill level and learning outcomes. It is a good practice to set up standards in a clustered approach for better results. Finally, the setting up of internal audit processes, procedures, infrastructure, mechanism and operational efficiency of all education sectors. Also, there is a serious need to develop an automated tool for risk management in education. The future researchers have to develop effective and customized risk management tool involving all the strategies and inbuilt application to identify, mitigate and resolve the risks in education sector. This in turn paves the way for a fruitful educational reform in the country as a whole.

\section{Conclusion}

The risk management in educational sector will focus on stakeholder participation, decentralized approach, effective policies with transparency in decision making, supporting regulatory environments for collaborations. It is to be noted that the risks associated with education projects can hamper the core functioning and it can create detrimental effect on the governance and economy of the country if there is no management strategy to mitigate them. Furthermore, the lack of effective risk management strategy can lead to emergence of more state monopolies leading to drastic effects like lack of transparent policies and accountability towards the objectives of education projects. Also, ineffective risk management strategy will lead to very slow phased innovation and also minimizes the choices available for sustainability of the education project. Hence, the risk management in education sector is quite indispensable towards effective implementation.

\section{References}

Berg, H. P. (2010). Risk Management: Procedures, Methods and Experiences, Reliability: Theory \& Applications, Vol.1, No.1, pp.79-95. 
Boehm, B. \& Turner, R. (2003). Using Risk to Balance Agile and Plan-Driven Methods, IEEE Computer, Vol.36, No.6, pp.57-66.

Huber, C. (2009). Risk and Risk Based Regulation in Higher Education Institutions, Tertiary Education and Management, Vol.15, No.2, pp.83-95.

Huber, M. (2010). Colonised by Risk. The Emergence of Academic Risks in British Higher Education, In: Hutter, B. M, Anticipating Risks and Organizing Risk Regulation in 21st Century, Ed., Cambridge University Press, Cambridge, United Kingdom, pp.114-135.

Larman, C. (2004). Agile and Iterative Development: A Manager's Guide, AddisonWesley Professional, Boston, USA, p.207.

Nikolic, B. \& Ruzic-Dimitrijevic, L. (2010). Distance Learning - From Idea to Realization, In Proceedings: Proceedings of Informing Science \& IT Education Conference, pp.369-384.

Nikolic, B. \& Ruzic-Dimitrijevic, L. (2012). A Model of the Vocational Higher Education School - The Practice as a Quality or a Deception and Delusion (Higher Vocational School Model - Practice as Quality or Deception And Misconception), XVIII Set Development Trends: Internationalization of the University, Serbia.

Popescu, M. \& Dascalu, A. (2011). Considerations on Integrating Risk and Quality Management, Annals of Dunarea de Jos University of Galati Fascicle I Economics and Applied Informatics, Vol.1, No.1, pp.49-54.

Prichinin, A. E. (2013). The Role of the Laws of the Educational Project In Minimizing Its Risks, Theoretical and Methodological Problems of Modern Education, In Proceedings: Materials of XIII International Scientific and Practical Conference, pp.222-225.

Ruzic-Dimitrijevic, L. \& Nikolic B. (2008). Designing and Building an Information System for a Higher Education, In Proceedings: Informing Science \& IT Education Conference, pp.283-300.

Thywissen, K. (2004). Core Terminology of Disaster Reduction: A Comparative Glossary in Measuring Vulnerability to Natural Hazards: Towards Disaster Resilient Societies, Ed., United Nations University Press, Bonn, Germany, pp.1-23.

Wisner, B. (2006). At Risk: Natural Hazards, People's Vulnerability and Disasters, $2^{\text {nd }}$ Edition, Routledge, London, United Kingdom, 464p. 